\title{
ON-LINE INTEGRATED SYSTEM FOR HUMAN RESOURCE SELECTION AND MONITORING IN VIRTUAL RESEARCH NETWORKS
}

Cotet, C.E.; Draghici, G.; BRINDASU, P.D. \& CARUTASU, G.

Abstract: The main goal of this paper is to present one of our research projects that is trying to implement a on-line informatic system for evaluating and handling the human and professional abilities. There are two specific complementary objectives: psychological evaluation of human resources compatibility with the specific research activities \& the evaluating of technical capacity for each member of the virtual team based on an adaptive map. The two objectives are complementary. For each person from the virtual team we will carry out a selection and a periodical evaluation that will include a psychological profile and a checking of the professional level. The testing system for the technical abilities will be used for the persons selection from a team of a project and to a periodically evaluation of the professional level

Key words: on-line system, research networks, quantifying grille, human resources, partnership
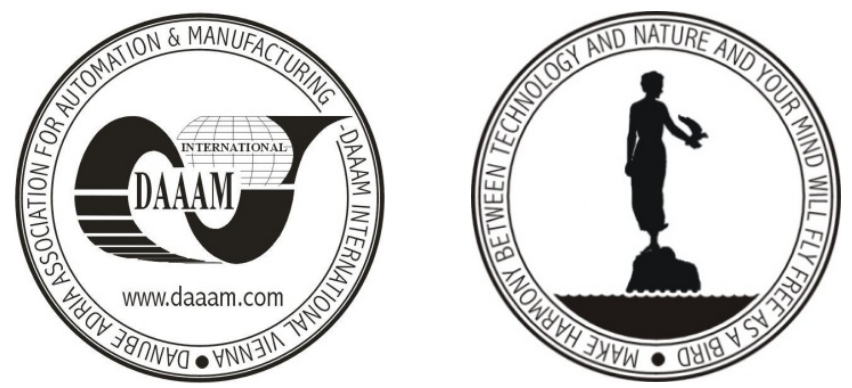

Authors' data: Dr. Ass. Prof. Cotet, C[ostel] E[mil]*; Prof. Draghici, G[eorge $]^{* *}$; Dr. Brindasu, $\mathrm{P}[\mathrm{aul}] \mathrm{D}[\mathrm{an}]^{* *}$; Prof. Univ.Sen.Lect. Dipl.-Ing. Dr. techn. Carutasu, G[eorge $]^{* * *}$, ${ }^{*}$ University Politehnica of Bucharest, IMST Faculty, MSP Department, UPBPREMINV Research Centre, 313, Splaiul Independentei, Sector 6, 060042, Bucharest, RO, **Politehnica University of Timisoara, Str. Salciei nr.1 sc.B ap.10, 300342, Timisoara, RO, ***Romanian-American University, 5th Croitoru V. St., 3rd Building, 39th Apartment, 5th District, Bucharest, 7000, Bucharest, RO, costel@mix.mmi.pub.ro, dan.brindau@ulbsibiu.ro,gdraghici@eng.upt.ro,georgecarutasu@yahoo.com

This Publication has to be referred as: Cotet, $\mathrm{C}$ [ostel] $\mathrm{E}[\mathrm{mil}]$; Draghici, G[eorge]; Brindasu, P[aul] D[an] \& Carutasu, G[eorge] (2008). On-Line Integrated System for Human Resource Selection and Monitoring in Virtual Research Networks, Chapter 21 in DAAAM International Scientific Book 2008, pp. 239-248, B. Katalinic (Ed.), Published by DAAAM International, ISBN 978-3-901509-66-7, ISSN 1726-9687, Vienna, Austria

DOI: $10.2507 /$ daaam.scibook.2008.21 